\title{
Compost Improves Urban Soil and Water Quality
}

\author{
Sally D. Logsdon ${ }^{*}$, Pat A. Sauer ${ }^{2}$, Martin J. Shipitalo ${ }^{1}$ \\ ${ }^{1}$ USDA-ARS-NLAE, 1015 N. University Blvd., Ames, IA, USA \\ ${ }^{2}$ Iowa Stormwater Education Partnership, Ames, IA, USA \\ Email: *sally.logsdon@ars.usda.gov
}

How to cite this paper: Logsdon, S.D., Sauer, P.A. and Shipitalo, M.J. (2017) Compost Improves Urban Soil and Water Quality. Journal of Water Resource and Protection, 9, 345-357.

https://doi.org/10.4236/jwarp.2017.94023

Received: January 31, 2017

Accepted: March 17, 2017

Published: March 20, 2017

Copyright (c) 2017 by authors and Scientific Research Publishing Inc. This work is licensed under the Creative Commons Attribution International License (CC BY 4.0).

http://creativecommons.org/licenses/by/4.0/

\section{Open Access}

\begin{abstract}
Construction in urban zones compacts the soil, which hinders root growth and infiltration and may increase erosion and degrade water quality. The purpose of our study was to determine whether planting prairie grasses and adding compost to urban soils should partially mitigate these concerns. We simulated construction activities by removing the topsoil, and compacting the soil by repeatedly driving over it with a tractor. Additionally, treatments included three compost application methods (compost and aeration, rototill and compost, surface compost). Plots were subjected to simulated rainfall applied using overhead sprinklers at a rate of 65 or $72 \mathrm{~mm} \cdot \mathrm{h}^{-1}$. Bulk density was significantly reduced in surface soil where compost had been added. Compost plus prairie grasses resulted in significantly faster infiltration (63 vs. $52 \mathrm{~mm} \cdot \mathrm{h}^{-1}$ ), slower runoff ( 4 vs. $25 \mathrm{~mm} \cdot \mathrm{h}^{-2}$ ), less soil loss ( $25 \mathrm{vs.} 119 \mathrm{~kg} \cdot \mathrm{Ha}^{-1} \cdot \mathrm{h}^{-1}$ ), and reduced loss of ortho P (57 vs. $410 \mathrm{~g} \cdot \mathrm{Ha}^{-1}$ ) compared to plots planted with bluegrass (Poa pratensis L.). A 5 to $7.5 \mathrm{~cm}$ thick compost blanket reduced time to runoff (60 $\mathrm{min}$ ) compared to no compost addition $(9 \mathrm{~min})$. Topsoil addition without compost did not develop dark surface soil. Compost additions are recommended to reduce negative effects of urban compaction. Over time, the depth of compost additions decreased, necessitating further additions.
\end{abstract}

\section{Keywords}

Degraded Soil, Compost, Rainfall Simulator, Soil Quality

\section{Introduction}

Urban construction sites usually result in compacted soils that limit infiltration [1] [2] [3] and plant growth [4] [5]. Reduced infiltration can result in ponding or runoff and erosion [6] [7] [8]. Whereas the results of most studies suggest that surface runoff and associated losses of nutrient are less than those from agricul- 
ture, the most critical factor affecting runoff is management [9].

Various management practices have been developed to restore urban soil quality [10]. For example, Singer et al. [11] noted that using an aerator combined with surface compost additions improved infiltration and plant growth. Olson et al. [12] observed that compost additions to compacted soil decreased bulk density and increased infiltration. Likewise, Faucette et al. [7] observed significantly reductions in runoff, sediment, and nitrate loss when compost was applied to urban soils.

The rate of compost addition should be high enough to aid plant growth, but not so great that excess nutrients are lost in runoff or leachate [13] [14] [15]. Johnson et al. [16] did not observe any significant increases in total phosphorus or nitrate loss for compost additions up to $99 \mathrm{~m}^{3} \cdot \mathrm{Ha}^{-1}(\sim 1 \mathrm{~cm}$ thick) on bluegrass. Likewise Loper et al. [17] did not observe significant increases in nitrate leaching after additions of composted dairy manure ( $\sim .5 \mathrm{~cm}$ thick) to turf; however, the compost increased nitrate leaching under ornamentals.

In addition to compost, native prairie grasses [18] and forbs [11] have greater rooting depth than normal lawn mixtures. Therefore, our hypothesis was that compost addition, with or without short prairie grasses, would improve soil and environmental quality in urban soils. The purpose of this study was to determine if compost, aeration, and/or prairie grasses should remediate a simulated urban construction site by reducing compaction and improving soil and water quality.

\section{Materials and Methods}

\subsection{Site Setup}

We tested our hypothesis by conducting two experiments. In Experiment 1, we compared soil physical properties and runoff under simulated rainfall of compacted plots planted with typical lawn species to plots with added compost and planted with prairie grasses. In Experiment 2, we compared three compost application methods on compacted urban soils.

\subsection{Experiment 1}

A 15 by $25 \mathrm{~m}$ urban site was prepared for the project (latitude, longitude: $41^{\circ} 41^{\prime} 4.312^{\prime \prime} \mathrm{N}, 93^{\circ} 35^{\prime} 29.143^{\prime \prime} \mathrm{W}$ ). Although not known at the time the project was started, the site contained 0.5 to $0.9 \mathrm{~m}$ of fill material added in 1997 (manuscript in preparation). Roundup ${ }^{\mathrm{TM}}$ was applied to the sod in the fall of 2007. After the sod died, the sod and surface soil were removed (between 0.12 and $0.3 \mathrm{~m}$ deep east to west), and the soil was stockpiled. Leaf and grass compost (Mulch Mart, Waukee, IA) was bought and covered with tarps for the winter. On 14 April 2008, the area was graded to $1 \%$ slope and the subsoil compacted by trafficking with a tractor.

On the control lawn half, topsoil was applied to $5 \mathrm{~cm}$ depth and rototilled in. On 12 May 2008, a commercial lawn mixture (C-3) was planted (30\% Kentucky bluegrass Poa pratensis L., 40\% perennial ryegrass Lolium perenne L., 30\% creeping red fescue Festuca rubra L. ssp. rubra) was planted at a rate of $412 \mathrm{~kg} \cdot \mathrm{Ha}^{-1}$. On 23 June 2008, fertilizer (6.4 kg of 10-20-10) was applied (170 kg.ha $\left.{ }^{-1}\right)$. 
On 8 May 2008, the other half of the area was remediated by using a tractor to pull a shallow $(15 \mathrm{~cm}$ ) homemade slotting tool (Figure 1) on the contour every $0.76 \mathrm{~m}$. Five $\mathrm{cm}$ of the stockpiled topsoil and $10 \mathrm{~cm}$ of compost was applied to this remediated area and incorporated using a rototiller. The prairie grasses Buffalo grass (Buchloe dactyloides (Nutt.) Engelm.) and Blue Grama grass (Bouteloua gracilis H.B.K.) (C-4 grasses) were each planted on the treatment side (194 $\mathrm{kg} \cdot \mathrm{ha}^{-1}$ each, 12 May 2008); however, the buffalo grass did not emerge well and was replanted 7 July 2008 by hand on the bare spots. The buffalo grass was seeded $0.3 \mathrm{~cm}$ deep with a rotary spreader. The blue grama grass seed was spread on the surface. Except for the compost, no fertilizer was applied to the remediated area. Both areas had straw applied 12 June 2008 to protect the soil.

On 8 July 2011, the original plots (Figure 1) were subdivided and half of each side was aerated first, and then top dressed with $1.27 \mathrm{~cm}$ of compost to replenish some of the original compost lost to decomposition or supply a small amount of compost to the control. The sites were periodically mowed, watered, and commercial fertilizer and weed killer were applied.

\subsection{Experiment 2}

On 8 to 9 July 2011, new smaller plots $(3.05$ by $3.05 \mathrm{~m}$ ) were established adjacent and around the original plots (Figure 2). As was done for Experiment 1, the sod was killed with glyphosate (Roundup ${ }^{\mathrm{TM}}$ ), and topsoil was removed and stockpiled. The plots were then graded to around $2 \%$ slope and then compacted by

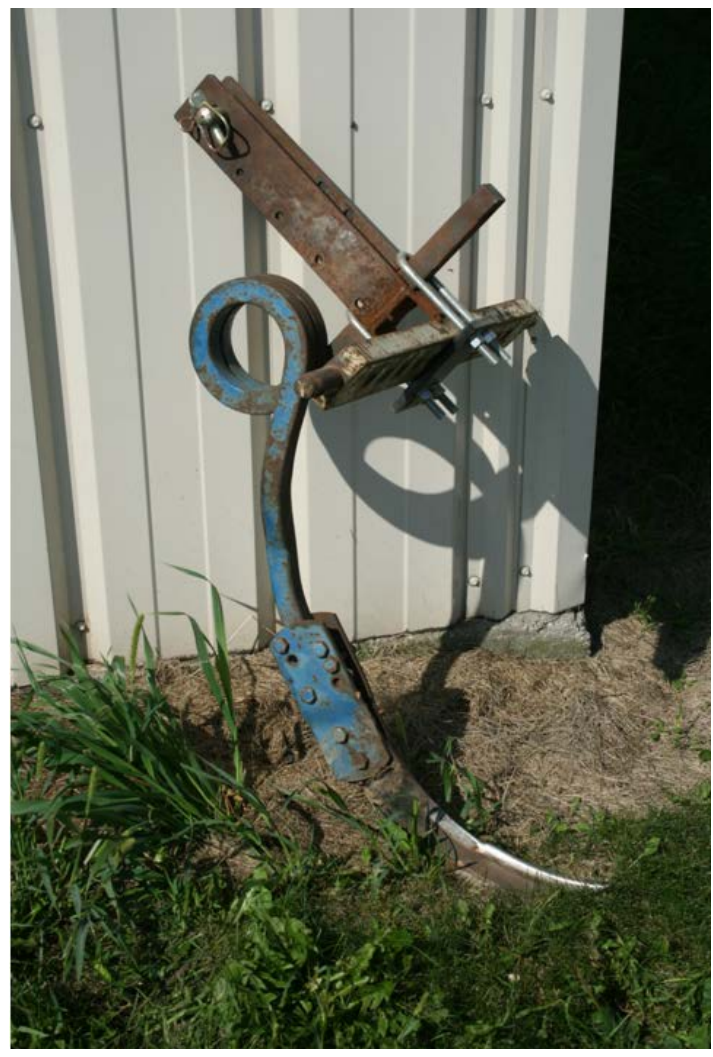

Figure 1. Homemade soil slotting tool used in Experiment 1. 


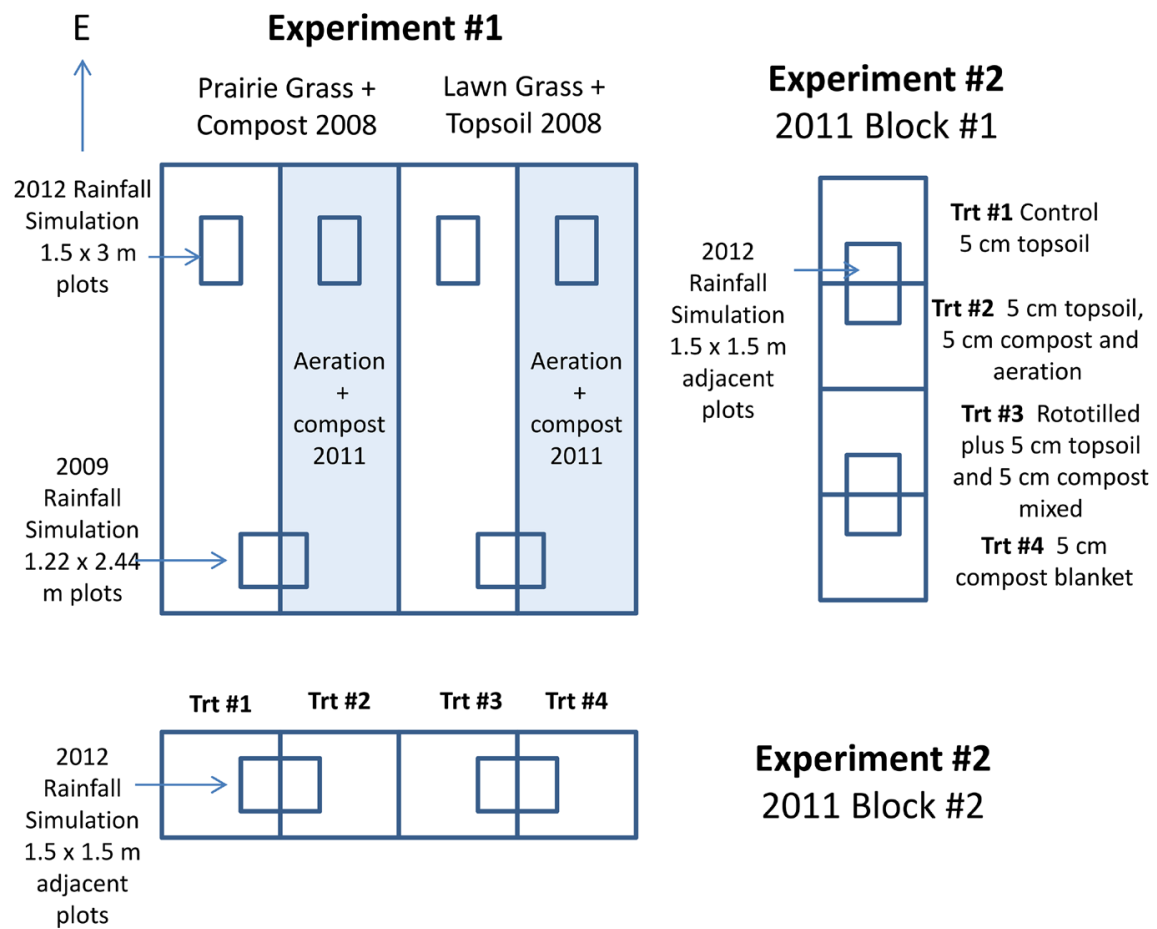

Figure 2. Layout of original plots (not to scale, total area 15 by $25 \mathrm{~m}$ ), established 2008, split in 2011 with compost and aeration addition to half, and new plots (each 3.05 by $3.05 \mathrm{~m}$ ) established 2011. Compost is given by $\mathrm{cmp}$, aeration by aer, rototill by till. The area for both experiments included grassed areas between plots was 29 m east-west, and 24 m northsouth.

driving over with a skid loader. There were four duplicated treatments. The control lawn treatment (Treatment 1 ) had $5 \mathrm{~cm}$ of topsoil spread on the surface. Treatment 2 had $5 \mathrm{~cm}$ of topsoil spread on the surface, then plug aerated with $5 \mathrm{~cm}$ of compost (Iowa State University Dairy Farm composted manure). Treatment 3 was rototilled first, and then covered with $5 \mathrm{~cm}$ of topsoil and $5 \mathrm{~cm}$ compost mixed. Treatment 4 had 5 to $7.5 \mathrm{~cm}$ of compost blanket spread on it. All treatments were hydromulched with a bluegrass mixture. The sites were periodically mowed, watered, and commercial fertilizer and weed killer were applied. For some years, grass seed was sprinkled in bare spots.

\subsection{Rainfall Simulations}

In August 2009, approximately 15 months after the topsoil and compost addition and planting of the original Experiment 1 plots, a rainfall simulator similar to that described by Byars et al. [19] was used to evaluate infiltration, runoff, and soil erosion in $1.22 \times 2.44 \mathrm{~m}$ plots (one plot for each of the two treatments). The rainfall intensity was $72 \mathrm{~mm} \cdot \mathrm{h}^{-1}$, which was applied from eight Rain Bird 8-VAN (Rain Bird, Corp., Azusa, CA) ${ }^{1}$ nozzles that were located along the perimeter of the rainfall simulator at $2.43-\mathrm{m}$ above the ground. The plots were constructed using steel borders that were inserted 6- $\mathrm{cm}$ deep along the sides and up-slope end. Runoff was collected at the down-slope end, where a V-shaped collector was placed above a collection trough. The V-shaped collector was inserted carefully 
to a depth that was level with the surface of the plot. Gaps present along this border were packed with soil excavated during the installation. Runoff from outside the plot was directed to two additional troughs located on each side of the center trough and was discarded. The runoff was measured every minute, and steady state conditions were assumed to have been established when runoff rates were constant for four consecutive minutes. Then runoff was collected every five minutes using a $30 \mathrm{~s}$ subsample. If the container became full before $30 \mathrm{~s}$, the exact amount of time required to fill the container was recorded. Soil cores measuring $1.9-\mathrm{cm}$ diameter $\times 30-\mathrm{cm}$ length were collected to determine antecedent and post-rainfall soil water content for each plot. The soil cores for antecedent water content were taken adjacent to each plot, and for the post-rainfall soil were taken within each plot. This rainfall simulation was conducted on the lower west end of the plots where there was fill material that was darker than that on the lawn area than the compost/prairie grass area.

A follow-up rainfall simulation study was conducted 17-20 September 2012 on the upper east end of the plots. As described above, the Experiment 1 plots were subdivided with half receiving $1.27 \mathrm{~cm}$ of compost and aerated July 2011. The rainfall simulations were conducted on $1.5 \mathrm{~m}$ by $3 \mathrm{~m}$ plots, using the procedures and simulator described by Kovar et al. [20]. The plots were oriented to allow water to flow down to metal sheet plates at the bottom edge. The simulator delivered rain at $65 \mathrm{~mm} \cdot \mathrm{h}^{-1}$ determined from calibration. Time to runoff was recorded. Runoff samples were collected at 2.5, 7.5, 12.5, 17.5, 22.5, and $27.5 \mathrm{~min}$ after a steady-stream of runoff was established. Total runoff from each plot was weighed to determine the amount.

Sub-samples of runoff were filtered in the field through $0.45 \mu \mathrm{m}$ cellulose acetate filter for ortho-P analysis. The rest of the runoff sample was mixed and subsampled for nitrate- $\mathrm{N}$, total $\mathrm{P}$, and sediment content. Measured concentrations were corrected by subtracting concentrations in the water used for the rainfall simulation. Nitrate plus nitrite nitrogen was measured with a Lachet Autoanalyzer using a Cd reduction [21] [22]. Total phosphorus was determined using flow injection analysis [23] [24] after acid-persulfate digestion. Runoff subsamples were dried at $105^{\circ} \mathrm{C}$ to determine sediment loss.

The rainfall simulator was too large to rain on individual Experiment 2 plots; therefore, the simulator was positioned so that two smaller $(1.5 \mathrm{~m} \times 1.5 \mathrm{~m})$ sideby-side plots could be rained on simultaneously, one nozzle per plot (Figure 2 and Figure 3). Metal sheeting in a V-shape was used to collect runoff at the bottom edge. Runoff samples were collected as for the large plots, but samples were not saved for nutrient analysis.

\subsection{Soil Water, Bulk Density, Morphology}

Six undisturbed soil cores $(7.4 \mathrm{~cm}$ diameter, $7.6 \mathrm{~cm}$ long) were collected to determine bulk density before soil disturbance related to construction of the Experimental 1 plots. Additional cores were taken in fall 2008 after disturbance and treatments had been imposed. For each treatment, five surface and subsurface cores 


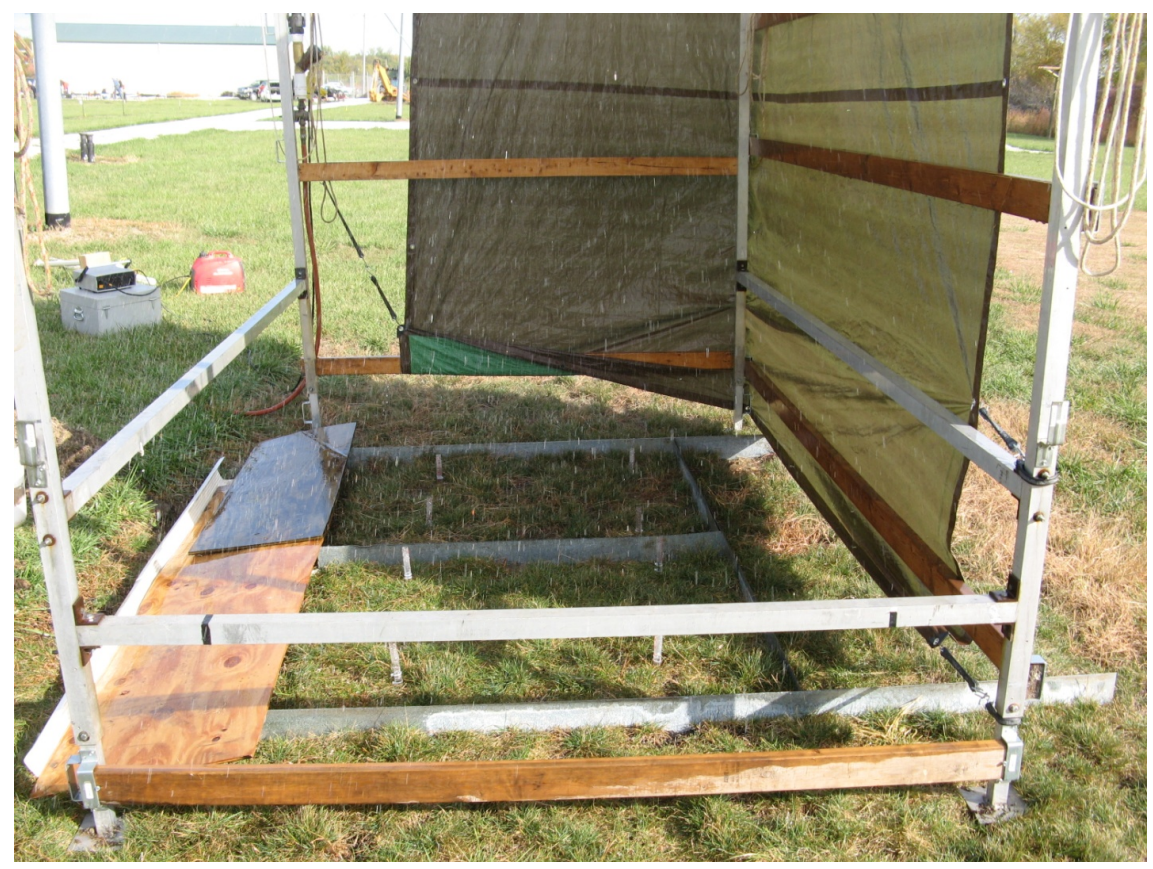

Figure 3. Rainfall simulation on side-by-side small plots in 2012. Note the tarp was used to block the wind and increase uniformity of simulated rainfall on the plots. Four small rain gages in each plot were used to assess the rainfall distribution.

were taken. The top of the subsurface depths were immediately beneath the surface-applied soil or compost.

Soil water content was monitored by measuring the real permittivity using a hydra probe (Stevens Vitel, Inc., Cantilly, VA) in all three studies. Experiment 1 was monitored in 2008 to 2010 (before the plots were subdivided and half were topdressed with compost), and 2012 to 2014 (after topdressing with compost). Experiment 2 was monitored 2012 to 2014. Three to ten spots were measured per treatment, using the calibration equation.

$\theta=-0.002+0.0608 \varepsilon_{a}^{1 / 2} \quad$ [25], in which $\theta$ was water content and $\varepsilon_{a}^{1 / 2}$ was the square root of the real permittivity.

On 26 October 2011, two undisturbed soil cores $(73 \mathrm{~mm}$ diameter and $76 \mathrm{~mm}$ high) were taken from each of the Experiment 1 plots that had addition of compost with aeration for both the surface and sub-surface soil. Two soil cores were also taken in the split side of the original Experiment 1 plots without the new aeration compost top dressing treatment. This was to determine the effect of the small compost additions.

In May 2015, undisturbed soil core samples were collected in plastic tubes $\sim 5$ $\mathrm{cm}$ diameter. These were used to determine the remaining depth of the surfaceapplied treatments as indicated by soil color with value/chroma of $3 / 2$ or darker.

\subsection{Statistics}

The large plots of Experiment 1 were not replicated; however, for the rainfall simulation study (after subdividing the plots), we treated the two measurements (original and zones with additional compost and aeration within the plot) as rep- 
licates. The small plots of Experiment 2 were true replicates. Data were analyzed by analysis of variance, and treatment mean differences using Tukey's Test. ANOVA and Tukey's Test were also used to compare yearly differences in soil water content among treatments.

\section{Results and Discussion}

\subsection{Experiment 1}

\subsubsection{Bulk Density}

Bulk density before compacting the soil was $1.39 \mathrm{~g} \cdot \mathrm{cm}^{-3}$ for the soil surface. In 2008 (after the plots were compacted, prepared, and planted) the surface bulk densities were $1.45 \mathrm{~g} \cdot \mathrm{cm}^{-3}$ for the bluegrass lawn and $1.11 \mathrm{~g} \cdot \mathrm{cm}^{-3}$ for the prairie compost large plots, whereas subsoil bulk densities for both treatments were 1.73 $\mathrm{g} \cdot \mathrm{cm}^{-3}$. These results indicated that the compaction treatment was successful in increasing bulk density. Similarly, Gregory et al. (2006) showed urban compaction significantly increased bulk density. When topsoil was replaced, the bulk density was slightly higher than before compaction. Adding compost lowered the bulk density of surface soil compared to the original condition.

In 2011 (three years after the initial treatments), the surface bulk densities were $1.30 \mathrm{~g} \cdot \mathrm{cm}^{-3}$ and $1.17 \mathrm{~g} \cdot \mathrm{cm}^{-3}$ for the bluegrass lawn and for the prairie-grass compost large plots. These results suggest that reduction in bulk density due to compost addition can persist for at least 3 yrs. Subsoil bulk densities were 1.62 $\mathrm{g} \cdot \mathrm{cm}^{-3}$ and $1.48 \mathrm{~g} \cdot \mathrm{cm}^{-3}$ for the bluegrass lawn and for the prairie-grass compost large plots. For the compost treated plot planted with prairie grasses, this indicated a reduction in subsoil bulk density relative to the topsoil alone treatment and the initial post-compaction subsoil bulk density. Over time these deep-rooted grasses reduced traffic-induced subsoil compaction. Johnson et al. [16] observed topdressing compost onto turf resulted in significantly lower bulk density.

\subsubsection{First Rainfall Simulation Experiment 1}

The rainfall simulator study of 2009 (15 months after establishing the plots) showed steady-state infiltration rates of 51.4 and $32.5 \mathrm{~mm} \cdot \mathrm{h}^{-1}$ for the lawn and for the compost/prairie grasses treatment. The sediment loss rate was $93 \mathrm{~kg} \cdot \mathrm{ha}^{-1} \cdot \mathrm{h}^{-1}$ for the lawn/control, but there was no measureable sediment loss from the compost/native grasses treatment despite having greater runoff rate $\left(40 \mathrm{vs.} 21 \mathrm{~mm} \cdot \mathrm{h}^{-1}\right)$. The soil water increase from the rain was 12.2 and $21.0 \mathrm{~mm}$ for the top $0.3 \mathrm{~m}$ depth of the lawn/control and the compost/native grasses treatment. Water contents before the applied rainfall were similar for the two treatments. The summary from the first rainfall simulation is that the lawn/control had greater infiltration rate and less runoff than the compost/prairie grassed, but more sediment loss. More of the simulated rainfall was retained in the upper $0.3 \mathrm{~m}$ of the compost-amended prairie grass plot than the lawn treatment.

\subsubsection{Second Rainfall Simulation}

When the second rainfall simulations were conducted in 2012, the grasses were well-established and the main plots had been subdivided (half of each receiving 
compost and aeration, Figure 2). When the two halves were treated as replicates (Table 1), the prairie-grass compost area compared with the bluegrass mix had significantly faster infiltration rate, slower runoff acceleration rate, less sediment loss, and reduce ortho-P and total $\mathrm{P}$ minus ortho-P loads. This rainfall simulator study was conducted on the east section of the plots where there was less treatment difference for depth of surface dark fill material. For both treatments, nitrate levels were at or below the concentrations in the supply water and are not reported.

Others show that urban compaction significantly reduces infiltration rates (i.e. [3]). Time to runoff for grass generally ranges from 2 to $15 \mathrm{~min}$ [26] [27]. Sediment loss from grass can range from 10 to $180 \mathrm{~kg} \mathrm{ha}^{-1}$ over $35 \mathrm{~min}$ [26], or from 0.1 to $104 \mathrm{~kg} \cdot \mathrm{ha}^{-1}$ per event of 12 to $30 \mathrm{~min}$ duration [28]. In our study, the soil was initially-dry and slopes were less-steep than for studies in the literature; therefore, we showed increased time to runoff compared with literature studies. Faucette et al. [7] observed that runoff and sediment loss from construction areas were reduced 3 months after applying poultry manure with other amendments.

Our P losses in runoff were at the low end for grassland, probably due to the small slopes in this study. Previous studies of $\mathrm{P}$ loss in runoff from grassland showed soluble $\mathrm{P}$ concentration ranging from 0.1 to $2.3 \mathrm{mg} \cdot \mathrm{L}^{-1}$ [27], and soluble $\mathrm{P}$ load ranging from 0.3 to $2.1 \mathrm{~kg} \cdot \mathrm{ha}^{-1}$ [29]. Total $\mathrm{P}$ concentrations in runoff can range from 0.3 to $7.1 \mathrm{mg} \cdot \mathrm{L}^{-1}$ [27], and total P loads can range from 0.4 to $2.5 \mathrm{~kg} \cdot \mathrm{ha}^{-1}$ [29].

\subsubsection{Soil Water Range of Difference}

The compost treatment held water more readily than the lawn treatment without compost. The range of difference for soil water content 2008 through 2010 was 0.180 and $0.235 \mathrm{~m}^{3} \cdot \mathrm{m}^{-3}$ for the control lawn and improved (compost + prairie grass).

Table 1. Rainfall simulator results (2012) and soil sampling as influenced by lawn treatments for Experiment 1 .

\begin{tabular}{lcc}
\hline \multicolumn{1}{c}{ Measure } & Prairie Compost & Bluegrass \\
\hline Time to runoff $(\mathrm{min})$ & $78 \mathrm{a}$ & $19 \mathrm{a}$ \\
Min. infiltration rate $\left(\mathrm{mm} \cdot \mathrm{h}^{-1}\right)$ & $63 \mathrm{a}$ & $52 \mathrm{~b}$ \\
Water increase $\left(\mathrm{m} \cdot \mathrm{m}^{-1}\right)$ & $0.11 \mathrm{a}$ & $0.11 \mathrm{a}$ \\
Runoff acceleration $\left(\mathrm{m} \cdot \mathrm{h}^{-2}\right)$ & $3.8 \mathrm{~b}$ & $24.6 \mathrm{a}$ \\
Sediment loss $\left(\mathrm{kg} \cdot \mathrm{ha} \mathrm{a}^{-1} \cdot \mathrm{h}^{-1}\right)$ & $25 \mathrm{~b}$ & $119 \mathrm{a}$ \\
Sediment concentration $\left(\mathrm{g} \cdot \mathrm{L}^{-1}\right)$ & $0.25 \mathrm{a}$ & $0.28 \mathrm{a}$ \\
Ortho-P $\left(\mathrm{mg} \cdot \mathrm{L}^{-1}\right)$ & $0.62 \mathrm{a}$ & $1.08 \mathrm{a}$ \\
Ortho P load $\left(\mathrm{kg} \cdot \mathrm{ha}^{-1}\right)$ & $0.057 \mathrm{~b}$ & $0.410 \mathrm{a}$ \\
Total-ortho-P $\left(\mathrm{mg} \cdot \mathrm{L}^{-1}\right)$ & $0.08 \mathrm{a}$ & $0.21 \mathrm{a}$ \\
Total-ortho-P $\left(\mathrm{kg} \cdot h \mathrm{ha}^{-1}\right)$ & $0.006 \mathrm{~b}$ & $0.078 \mathrm{a}$ \\
\hline
\end{tabular}

Means followed by the same letter within a row are not significantly different at $\mathrm{p}=0.05$ by Tukey's test. 
The range of soil water content 2013 was 0.038 , and $0.194 \mathrm{~m}^{3} \cdot \mathrm{m}^{-3}$ for control and improved areas, which was significantly different. A larger range suggested better water holding capacity for the improved area. The differences in 2014 were not significant: 0.102 and $0.181 \mathrm{~m}^{3} \cdot \mathrm{m}^{-3}$ for the control or improved areas. In general, water content was related to time of year since C-3 lawn grasses are more active in the spring and fall, and warm season C-4 blue gamma grass is more active in the summer (not shown).

Other researchers have investigated the effect of compost additions on soil water. Johnson et al. [16] did not observe any effect of topdressing compost onto turf on soil water content. In contrast, Singer et al. [11] showed that compost increased soil water content at an urban site only soon after rain events, and soil water content was increased more when the compost was incorporated than for surface applications. Too much water can result in aeration problems on compacted soil [4].

\subsubsection{Treatment Depth}

Samples taken in 2015 (Table 2) showed that some of the original applied compost or topsoil (indicated by dark soil) was no longer visible, having been lost to settling and oxidation. When $1.3 \mathrm{~cm}$ of compost was added in 2011, the treatment depth effect was even greater at $5 \mathrm{~cm}$. The compost with prairie grasses still showed $6 \mathrm{~cm}$ of treatment depth, but only $6.5 \mathrm{~cm}$ when $1.3 \mathrm{~cm}$ compost was added in 2011. Olson et al. [12] suggested that if compost plus tillage increased root growth, the roots themselves could provide continual soil structure improvement even as the compost degrades over time.

\subsection{Experiment 2}

\subsubsection{Rainfall Simulation}

The small plots showed the compost blanket treatment significantly increased the time to runoff compared with the no compost treatment, but there were no

Table 2. Soil inflence from applied treatments, 4 to 8 years later.

\begin{tabular}{lccc}
\hline \multicolumn{1}{c}{ Treatment } & Years (s) & Applied depth & Depth remain 2015 \\
\hline Experiment 1 & \multicolumn{1}{c}{$\mathrm{cm}$} & $\mathrm{cm}$ \\
Topsoil + rototilled & 2008 & 5 & 0 \\
Add compost & 2011 & $(5)+1.3$ & 5 \\
Topsoil + rototill + compost & 2008 & 10 & 6 \\
Add compost & 2011 & $(10)+1.3$ & 6.5 \\
Experiment 2 & & & 0 \\
TMT 1 topsoil & 2011 & 5 & 4.5 \\
TMT 2 topsoil + compost + aeration & 2011 & 10 & 8.5 \\
TMT 3 compost + rototill & 2011 & 10 & 2.5 \\
TMT 4 compost blanket & 2011 & 6.5 & \\
\hline
\end{tabular}

${ }^{\mathrm{T}} \mathrm{TMT}$ is treatment. 
significant difference among treatments noted for the other runoff parameters measured (Table 3). As noted for Experiment 1, our runoff time was longer and sediment loss was lower than observed in other studies [26] [27] probably due to small slopes in our study.

\subsubsection{Soil Properties}

Surface bulk density was significantly greater for the no compost treatment that for compost with aeration or compost with tillage (Table 2). The new control that only had topsoil added showed no dark soil left in 2015 (Table 3). The treatment with compost that had been rototilled showed dark soil over $8 \mathrm{~cm}$ deep.

\subsubsection{Soil Water Annual Range of Difference}

Higher bulk densities resulted in numerically higher water contents in the top 10 $\mathrm{cm}$ for the control lawn with no compost (Treatment 1) compared with other treatment (not shown). The ranges of water content for 2012 were $0.206,0.214$, 0.236 , and $0.221 \mathrm{~m}^{3} \cdot \mathrm{m}^{-3}$ for control, compost + aeration, compost + rototilled, and compost blanket. Similarly the water content ranges for 2013 were 0.110, $0.131,0.123$, and $0.118 \mathrm{~m}^{3} \cdot \mathrm{m}^{-3}$ for the same treatments. Also for 2014 the range of water contents for 2014 were $0.163,0.184,0.076$, and $0.134 \mathrm{~m}^{3} \cdot \mathrm{m}^{-3}$ for the same treatments. None of these differences were significant, but the treatments that received compost tended to have higher differences in soil water content over the year. The higher difference in soil water content suggested a trend toward greater water holding capacity where the compost was added.

\section{Conclusions and Recommendations}

Compost reduced bulk density in the surface soil. Compost with prairie grasses

Table 3. Rainfall simluator and soil sampling results (2012) as influence by lawn treatments, Experiment 2.

\begin{tabular}{|c|c|c|c|c|}
\hline Measure & $\begin{array}{c}\text { Trt\#1 } \\
\text { No } \\
\text { compost }\end{array}$ & $\begin{array}{c}\text { Trt\#2 } \\
\text { Aerate/ } \\
\text { compost }\end{array}$ & $\begin{array}{c}\text { Trt\#3 } \\
\text { Till/ } \\
\text { compost }^{\mathrm{a}}\end{array}$ & $\begin{array}{c}\text { Trt\#4 } \\
\text { Compos } \\
\text { blanket }\end{array}$ \\
\hline \multicolumn{5}{|l|}{ Runoff } \\
\hline Time to runoff ( $\mathrm{min})$ & $9 b^{b}$ & $51 \mathrm{ab}$ & 27 & $60 \mathrm{a}$ \\
\hline Minimum infiltration rate $\left(\mathrm{mm} \cdot \mathrm{h}^{-1}\right)$ & $42 \mathrm{a}$ & $57 \mathrm{a}$ & 64 & $47 \mathrm{a}$ \\
\hline Water increase $\left(\mathrm{m} \cdot \mathrm{m}^{-1}\right)$ & 0.16 & 0.17 & 0.15 & 0.21 \\
\hline Soil loss $\left(\mathrm{kg} \cdot \mathrm{ha}^{-1} \cdot \mathrm{h}^{-1}\right)$ & $297 \mathrm{a}$ & $122 \mathrm{a}$ & 26 & $204 a$ \\
\hline Soil concentration & $0.40 \mathrm{a}$ & $0.37 \mathrm{a}$ & 0.25 & 0.35 \\
\hline \multicolumn{5}{|l|}{ Soil properties } \\
\hline Bulk density $\left(0-0.1 \mathrm{~m}, \mathrm{~g} \cdot \mathrm{cm}^{-3}\right)$ & $1.34 \mathrm{a}$ & $0.98 b c$ & $0.87 \mathrm{c}$ & $1.13 \mathrm{ab}$ \\
\hline Bulk density $\left(0.1-0.2 \mathrm{~m}, \mathrm{~g} \cdot \mathrm{cm}^{-3}\right)$ & $1.37 \mathrm{a}$ & $1.39 \mathrm{a}$ & 1.28 & $1.25 \mathrm{a}$ \\
\hline
\end{tabular}


significantly increased infiltration and reduced runoff and sediment loss compared with bluegrass lawn. Compost additions made the surface soil darker than merely adding topsoil.

More than minimal compost additions showed some improved soil quality of post-construction soils. Although establishment was slow, the prairie grasses eventually resulted in a dense sod that reduced runoff, and erosion, and surface P loss. Over time, the compost was decomposed, so periodic refreshment of a compost blanket would be recommended.

\section{Acknowledgements}

Thanks to Gavin Simmons for field data collection, Jeff Cook for rainfall simulator assistance, and Amy Morrow for analytical laboratory support.

\section{References}

[1] Kelling, K.A. and Peterson, A.E. (1975) Urban Lawn Infiltration Rates and Fertilizer Runoff Losses under Simulated Rainfall. Soil Science Society of America Proceedings, 39, 348-352. https://doi.org/10.2136/sssaj1975.03615995003900020031x

[2] Hamilton, G.W. and Waddington, D.V. (1999) Infiltration Rates on Residential Lawns in Central Pennsylvania. Journal of Soil and Water Conservation, 54, 564568.

[3] Gregory, J.H., Dukes, M.D., Jones, P.H. and Miller, G.L. (2006) Effect of Urban Compaction on Infiltration Rate. Journal of Soil and Water Conservation, 61, 117123.

[4] O’Neil, K.J. and Carrow, R.N. (1983) Perennial Ryegrass Growth, Water Use and Soil Aeration Status under Soil Compaction. Agronomy Journal, 75, 177-180. https://doi.org/10.2134/agronj1983.00021962007500020005x

[5] Partsch, C.M., Jarrett, A.R. and Watschke, T.L. (1993) Infiltration Characteristics of Residential Lawns. Transactions of ASAE, 36, 1695-1701. https://doi.org/10.13031/2013.28513

[6] Knox, E.G., Bouchard, C.E. and Barrett, J.G. (2000) Erosion and Sedimentation in Urban Areas. In: Brown, R.B., et al., Eds., Managing Soils in an Urban Environment, Agronomy Monograph 39, ASA-CSSA-SSSA, Madison, 179-197.

[7] Faucette, L.B., Jordan, C.F., Risse, L.M., Cabrera, M., Coleman, D.C. and West, L.T. (2005) Evaluation of Stormwater from Compost and Conventional Erosion Control Practices in Construction Activities. Journal of Soil and Water Conservation, 60, 288-297.

[8] Maniquiz, M.C., Lee, S., Lee, E., Kong, D.-S. and Kim, L.-H. (2009) Unit Soil Loss Rate from Various Construction Sites during a Storm. Water Science Technology, 59, 2187-2196. https://doi.org/10.2166/wst.2009.255

[9] King, K.W. and Balogh, J.C. (2008) Nutrient and Pesticide Transport in Surface Runoff from Perennial Grasses in the Urban Landscape. In: Beard, J.B. and Keens, M.P., Eds., Water Quality and Quantity Issues for Turfgrasses in Urban Landscapes, Chapter 8, Council for Agriculture Science and Technology, Ames, 121-152.

[10] Adamson, D., Bazter, D., Foster, A., Griffin, J., Kauten, R., Masteller, M., Petersen, W., Pierce, G., Sauer, P., Stineman, B. and Welch, J. (2014) Section 2E-6-Soil Quality Management and Restoration. Iowa Stormwater Management Manual, 1-20.

[11] Singer, J.W., Malone, R.W., Tomer, M.D., Meade, T.G. and Welch, J. (2006) Compost Effect on Water Retention and Native Plant Establishment on a Construction 
Embankment. Journal of Soil and Water Conservation, 61, 268-273.

[12] Olson, N.C., Gulliver, J.S., Nieber, J.L. and Kayhanian, M. (2013) Remediation to Improve Infiltration into Compact Soils. Journal of Environmental Management, 117, 85-95. https://doi.org/10.1016/j.jenvman.2012.10.057

[13] Linde, D.T., Watchke, T.L., Jarrett, A.R. and Borger, J.A. (1995) Surface Runoff Assessment from Creeping Bentgrass and Perennial Ryegrass Turf. Agronomy Journal, 87, 176-182. https://doi.org/10.2134/agronj1995.00021962008700020007x

[14] Glanville, T.D., Persyn, R.A., Richard, T.L., Laflen, J.M. and Dixon, P.M. (2004) Environmental Effects of Applying Composted Organics to New Highway Embankments: Part 2. Water Quality. Transactions of ASAE, 47, 471-478.

https://doi.org/10.13031/2013.16051

[15] Saebo, A. and Ferrini, F. (2006) The Use of Compost in Urban Green Areas-A Review of Practical Application. Urban Forest and Urban Greening, 4, 159-169. https://doi.org/10.1016/j.ufug.2006.01.003

[16] Johnson, G.A., Davis, J.G., Qian, Y.L. and Doesken, K.C. (2006) Topdressing Turf with Composted Manure Improves Soil Quality and Protects Water Quality. Soil Science Society of America Journal, 70, 2114-2121.

https://doi.org/10.2136/sssaj2005.0287

[17] Loper, S.J., Shober, A.L., Wiese, C., Denny, G.C. and Stanley, C.D. (2013) Nutrient Leaching during Establishment of Simulated Residential Landscapes. Journal of Environmental Quality, 42, 260-270. https://doi.org/10.2134/jeq2012.0098

[18] Mahaney, W.M. (2010) Plant Controls on Decomposition Rates: The Benefits of Restoring Abandoned Agricultural Lands with Native Prairie Grasses. Plant and Soil, 330, 91-101. https://doi.org/10.1007/s11104-009-0178-8

[19] Byars, B.W., Allen, P.M. and Bingham, N.L. (1996) A Portable Rainfall Simulator for Assessing Infiltration. Journal of Soil and Water Conservation, 51, 508-510.

[20] Kovar, J.L., Moorman, T.B., Singer, J.W., Cambardella, C.A. and Tomer, M.D. (2011) Swine Manure Injection with Low-Disturbance Applicator and Cover Crops Reduce Phosphorus Losses. Journal of Environmental Quality, 40, 329-336. https://doi.org/10.2134/jeq2010.0184

[21] Wood, E.D., Armstrong, F.A.J. and Richards, F.A. (1967) Determination of Nitrate in Seawater by Cadmium-Copper Reduction to Nitrite. Journal of the Marine Biological Association of the United Kingdom, 47, 23-31. https://doi.org/10.1017/S002531540003352X

[22] Tomer, M.D., Moorman, T.B. and Rossi, C.G. (2008) Assessment of the Iowa River's South Fork Watershed: Part 1. Water Quality. Journal of Soil and Water Conservation, 63, 360-370. https://doi.org/10.2489/jswc.63.6.360

[23] U.S. Environmental Protection Agency (1993) EPA 365.1: Determination of Phosphorus by Semi-Automated Colorimetry, Revision 2.0.

https://www.epa.gov/sites/production/files/2015-08/documents/method_365-1_199 3.pdf

[24] U.S. Environmental Protection Agency (1978) EPA 365.3: Phosphorous, All Forms (Colorimetric, Ascorbic Acid, Two Reagent).

https://www.epa.gov/sites/production/files/2015-08/documents/method_365=3_197 8.pdf

[25] Logsdon, S.D. and Hornbuckle, B. (2006) Soil Moisture Probes for Dispersive Soils. 3 rd International Symposium and Workshop on Time Domain Reflectometry for Innovative Soils Applications, West Lafayette, 17-20 September 2006, Paper No. 13. https://engineering.purdue.edu/TDR/Papers/13_Paper.pdf 
[26] Krenitsky, E.C., Carroll, M.J., Hill, R.L. and Krouse, J.M. (1998) Runoff and Sediment Losses from Natural and Man-made Erosion Control Materials. Crop Science, 38, 1042-1046. https://doi.org/10.2135/cropsci1998.0011183X003800040026x

[27] Ramirez-Avila, J.J., Stomayor-Ramirez, D., Martinez-Rodrguez, G.A. and PerezAegria, L.R. (2011) Phosphorus in Runoff from Two Highly Weathered Soils of the Tropics. Canadian Journal of Soil Science, 91, 267-277. https://doi.org/10.4141/cjss10064

[28] Soldat, D.J. and Petrovic, A.M. (2008) The Fate and Transport of Phosphorus in Turfgrass Ecosystems. Crop Science, 48, 2051-2065. https://doi.org/10.2135/cropsci2008.03.0134

[29] Franklin, D.H., Cabrera, M.L. and Calvert, V.H. (2006) Fertilizer Source and Soil Aera-tion Effects on Runoff Volume and Quality. Soil Science Society of America Journal, 70, 84-89. https://doi.org/10.2136/sssaj2003.0114

\section{Submit or recommend next manuscript to SCIRP and we will provide best} service for you:

Accepting pre-submission inquiries through Email, Facebook, LinkedIn, Twitter, etc. A wide selection of journals (inclusive of 9 subjects, more than 200 journals)

Providing 24-hour high-quality service

User-friendly online submission system

Fair and swift peer-review system

Efficient typesetting and proofreading procedure

Display of the result of downloads and visits, as well as the number of cited articles Maximum dissemination of your research work

Submit your manuscript at: http://papersubmission.scirp.org/

Or contact jwarp@scirp.org 